\title{
A comparative study on different metal loaded soybean milk by-product 'okara' for biosorption of phosphorus from aqueous solution
}

\author{
T.A.H. Nguyen ${ }^{a}$, H.H. Ngo ${ }^{a, *}$, W.S. Guo ${ }^{a}$, T.V. Nguyen ${ }^{a}$, J. Zhang ${ }^{b}$, S. Liang ${ }^{b}$, S.S. Chen ${ }^{c}$, N.C. Nguyen ${ }^{c}$ \\ ${ }^{a}$ Centre for Technology in Water and Wastewater, School of Civil and Environmental Engineering, University of Technology, Sydney, Broadway, NSW 2007, Australia \\ ${ }^{b}$ Shandong Key Laboratory of Water Pollution Control and Resource Reuse, School of Environmental Science E' Engineering, Shandong University, Jinan 250100, PR China \\ ${ }^{\mathrm{c}}$ Institute of Environmental Engineering and Management, National Taipei University of Technology, No. 1, Sec. 3, Chung-Hsiao E. Rd, Taipei 106, Taiwan, ROC
}

\section{H I G H L I G H T S}

- ZLO was superior to IZLO and ILO, especially in terms of affinity and reusability.

- ZLO could remove $97 \% \mathrm{P}$ at the initial concentration of $50 \mathrm{mg} / \mathrm{L}$, dose of $10 \mathrm{~g} / \mathrm{L}$.

- $0.2 \mathrm{M} \mathrm{NaOH}$ was suitable for elution of P from ZLO with the efficiency of $94.25 \%$.

- No Zr(IV) leakage was observed during adsorption and desorption tests using ZLO.

- Activation of desorbed ZLO with $0.1 \mathrm{M} \mathrm{HCl}$ was necessary for ZLO to be recycled.

\section{A R T I C L E I N F O}

\section{Article history:}

Received 30 March 2014

Received in revised form 21 June 2014

Accepted 23 June 2014

Available online 8 July 2014

\section{Keywords:}

Metal loaded okara

Phosphorus removal

Biosorption

Desorption

Reusability

\begin{abstract}
A B S T R A C T
Cationization of agricultural by-products using metal salts is widely used to activate their phosphorous capture ability. This study developed three kinds of new metal loaded soybean milk by-product 'okara' for phosphorus biosorption. A comparative study among these biosorbents was carried out with respect to their performances in terms of affinity, stability and reusability. Zirconium loaded okara (ZLO) was found to have the highest affinity towards $\mathrm{PO}_{4}^{3-}$ anions $(47.88 \mathrm{mg} / \mathrm{g})$, followed by iron/zirconium loaded okara - IZLO $(40.96 \mathrm{mg} / \mathrm{g})$ and iron loaded okara - ILO $(16.39 \mathrm{mg} / \mathrm{g})$. ZLO was successfully desorbed with $0.2 \mathrm{M} \mathrm{NaOH}$ and activated with $0.1 \mathrm{HCl}$ prior to the next cycle. After five consecutive cycles, the efficiency of both adsorption and desorption of ZLO remained about $85 \%$ whilst no $\operatorname{Zr}(\mathrm{IV}$ ) leakage was observed. Conversely, IZLO and ILO suffered from vital short comings such as high metal release and/or sharp reduction in $\mathrm{PO}_{4}^{3-}$ sequestering capability after multi operation cycles.
\end{abstract}

๔ 2014 Elsevier Ltd. All rights reserved.

\section{Introduction}

Phosphorus is known as an essential element to the plant growth (Ismail, 2012). It is also a key constituent of deoxyribonucleic acid (DNA), teeth and bones in animal bodies (Biswas et al., 2008). Moreover, it is a fundamental material for many industries, including fertilizers, detergents, pharmaceuticals, beverages, paints and corrosion inhibitors (Biswas et al., 2007). Nevertheless, due to the overexploitation for different uses, the global rock phosphorus reserves are at the risk of being exhausted in 50-100 years (Eljamal et al., 2013; Ogata et al., 2012). Thus, there is an urgent

\footnotetext{
* Corresponding author. Address: School of Civil and Environmental Engineering, University of Technology, Sydney (UTS), P.O. Box 123, Broadway, NSW 2007, Australia. Tel.: +6129514 2745; fax: +61295142633.

E-mail address: ngohuuhao121@gmail.com (H.H. Ngo).
}

need to search for alternative sources of phosphorus (Anirudhan et al., 2006; Zhang et al., 2012).

In another perspective, phosphorus is considered as a pollutant that causes eutrophication with the concentration in receiving water of higher than $0.02 \mathrm{mg} / \mathrm{L}$ (Jyothi et al., 2012; Mallampati and Valiyaveettil, 2013). To protect aquatic medium from eutrophication, in many countries, phosphorus level is regulated to be lower than $0.05 \mathrm{mg} / \mathrm{L}$, if streams discharge into lakes or reservoirs (Benyoucef and Amrani, 2011). As a result, the elimination of phosphorus from effluents before discharging is mandatory (Kalmykova et al., 2013). In addition, the removal of phosphorus enables its recovery for the substitution of depleting phosphorus ores.

So far, numerous available technologies for controlling $\mathrm{PO}_{4}^{3-}$ pollution can be grouped into chemical, biological and physical methods (Benyoucef and Amrani, 2011; Bhojappa, 2009). Though chemical precipitation and biological processes are most commonly used, adsorption has attracted an increasing attention, with 
dominant advantages of being effective, best suited for low levels of $\mathrm{PO}_{4}^{3-}$, and favorable to $\mathrm{PO}_{4}^{3-}$ recovery (Li et al., 2009; Loganathan et al., 2013; Zhang et al., 2011). Due to drawbacks of commercial adsorbents (e.g. high cost, non-renewability), there is lately an emerging trend to use agricultural wastes/by-products (AWBs) based biosorbents for this purpose.

Due to the lack of anion binding sites on their surface, most of AWBs in the natural form are inefficient in removing $\mathrm{PO}_{4}^{3-}$ from aqueous solutions (Eberhardt and Min, 2008). Thus, to augment their affinity toward $\mathrm{PO}_{4}^{3-}$, AWBs need to be cationized, which can be implemented via metal loading, hybridizing with inorganic chemicals, and grafting with ammonium type chemicals (Han et al., 2005; Mallampati and Valiyaveettil, 2013). Metal loading is usually a method of choice because of its simplicity and efficiency. Although much research has been done on the removal of $\mathrm{PO}_{4}^{3-}$ using metal loaded AWBs based biosorbents, their practical application is still limited. This can be attributed to the fact that the stability and reusability of biosorbents have usually received far less attention than their adsorption and desorption capacities.

Okara is one of the well-known agricultural by-products, which is collected from production of soymilk, tofu and their derivatives. It can have different names, such as soybean milk residue, soy pulp, soy fines, bean mash, bean curd dreg (English), le okara (French), das okara (German), tofuzha, douzha or doufuzha (Chinese), tofukasu (Japanese), piji (Korean), sapal (Filipino), ampastahu (Indonesian), tauhu tor (Thai). The production of every $1000 \mathrm{~L}$ of soy beverage can result in $250 \mathrm{~kg}$ of okara (Soy 20/20, 2014). Based on the soy beverage consumption, it is estimated that around 14 million tons of okara are annually generated worldwide. As okara contains $50 \%$ fiber, $25 \%$ protein, $10 \%$ lipid, and other nutrients, it is desirable to use okara as animal feed, fermentation substrate, fertilizer, pet food, food production, etc. However, the rapid degradation, high cost of drying, feasibility of freezing, etc. are major barriers to the use of okara in food. Currently, okara is mostly dumped or burned as waste, except for a small quantity, which is occasionally used as animal feed (Li et al., 2012). This can pose a risk to the environment. Consequently, there is a need to develop useful products from this waste material. Some types of soybean by-products were used as environmentally friendly materials in water treatment, such as soybean hulls (Marshall and Wartelle, 2004); lees materials (Adachi et al., 2005); bean dregs (Li, 2009); and okara. It was found that these materials exhibit diverse sorption capabilities toward anions (e.g. $\mathrm{AsO}_{4}^{3-}, \mathrm{CrO}_{4}^{2-}, \mathrm{Cr}_{2} \mathrm{O}_{7}^{2-}, \mathrm{PO}_{4}^{3-}$, $\mathrm{SeO}_{4}^{2-}$ ); organochlorine compounds or benzene; heavy metals $\left(\mathrm{Cu}^{2+}, \mathrm{Zn}^{2+}\right)$; dyes (acid red 14 and reactive red 15 ), respectively. However, to the best of the authors' knowledge, no previous studies have reported the application of okara for phosphate pollution remediation.

Okara was chosen for investigation in this study because of its insolubility in water, non-toxicity, low cost, easy acquiring, and abundant availability. Moreover, the present research finds that okara has phosphorous inside itself (188-260 mg P/100 g dry okara). This can provide a foundation for the recovery of phosphorus from both original okara and wastewater. Due to the poor ability of pristine okara in eliminating phosphorus from aqueous solution, modified okara was prepared and utilized for this purpose. The 7 previous study with iron load okara (ILO) demonstrated an unsatisfying adsorption capacity $\left(4.785 \mathrm{mg} \mathrm{PO}_{4} / \mathrm{g}\right)$, and the vigorous detachment of $\mathrm{Fe}(\mathrm{III})$ during operation (Nguyen et al., 2013). Hence, the objective of this work is to develop new kinds of metal loaded okara, which hold enhanced adsorption capacity and superior stability. Particularly, for the very first time, the recyclability of new biosorbents was investigated. This paper reported results from adsorption experiments, desorption studies, stability and reusability investigations. Based on the obtained results, the best suitable metal loaded okara was recommended.

\section{Methods}

\subsection{Chemicals}

All chemicals used in this study were of analytical grade.

The stock solution of phosphorus $(1000 \mathrm{mg} / \mathrm{L})$ was prepared by dissolving $4.58 \mathrm{~g}$ of disodium hydrogen phosphate $\left(\mathrm{Na}_{2} \mathrm{HPO}_{4}\right)$ in a $1000 \mathrm{ml}$ of milli-Q water. The working solutions of phosphorus (10, $25,50,100,125,200,250,400,500 \mathrm{mg} \mathrm{P} / \mathrm{L}$ ) were prepared by diluting the stock solution $(1000 \mathrm{mg} \mathrm{P} / \mathrm{L})$ with milli-Q water accordingly (100, 40, 20, 10, 8, 5, 4, 2.5, 2 times).

$0.05 \mathrm{M}$ and $0.2 \mathrm{M} \mathrm{NaOH}$ solutions: 2 and $8 \mathrm{~g}$ of sodium hydroxide $(\mathrm{NaOH})$, respectively were dissolved in $1000 \mathrm{ml}$ of milli-Q water.

$0.25 \mathrm{M} \mathrm{Fe}(\mathrm{III})$ solution:40.55 g of ferric chloride $\left(\mathrm{FeCl}_{3}\right)$ was dissolved in $1000 \mathrm{ml}$ of milli-Q water.

$0.25 \mathrm{M} \mathrm{Zr}$ (IV) solution: $80.56 \mathrm{~g}$ of zirconyl chloride octahydrate $\left(\mathrm{ZrOCl}_{2} 8 \mathrm{H}_{2} \mathrm{O}\right)$ was dissolved in $1000 \mathrm{ml}$ of milli-Q water.

\subsection{Preparation of metal loaded okara}

Fresh okara was obtained from soybean milk production at home with Lumina glass blender (Model No BL-805C). $1 \mathrm{~kg}$ of okara was obtained from 4 liters of soybean milk. Prior to chemical modifications, fresh okara was washed on a sieve of $300 \mu \mathrm{m}$ with tap water, and then with distilled water to remove the residual milk. It was then dried in the oven at $105^{\circ} \mathrm{C}$ for $24 \mathrm{~h}$, and kept in a desiccator prior to further treatment.

To prepare single metal loaded okara (ILO and ZLO), the dried raw okara was first stirred with $0.05 \mathrm{M} \mathrm{NaOH}$ at the following conditions: solid/liquid ratio of $1 \mathrm{~g} / 20 \mathrm{ml}$, stirring speed of $120 \mathrm{rpm}$, room temperature, and contact time of $24 \mathrm{~h}$. Secondly, $\mathrm{NaOH}$ treated okara was washed with tap water, and then with distilled water until $\mathrm{pH}$ of the washing solution was almost neutral. Next, it was dried in the oven at $105^{\circ} \mathrm{C}$ for $24 \mathrm{~h}$ and cooled down to the ambient condition. Dried $\mathrm{NaOH}$ treated okara was then stirred with $0.25 \mathrm{M} \mathrm{Fe}(\mathrm{III})$ or $0.25 \mathrm{M} \mathrm{Zr}$ (IV) at the above condition. After washing with tap water and then with distilled water to remove all free metal ions on the surface, the materials were dried in the oven at $105^{\circ} \mathrm{C}$ for $24 \mathrm{~h}$ and cooled down to the room temperature.

To prepare combined metal loaded okara (IZLO), the dried raw okara was pretreated with $0.05 \mathrm{M} \mathrm{NaOH}$ and then loaded with $0.25 \mathrm{M} \mathrm{FeCl}_{3}$ as mentioned above. Next, the dried $\mathrm{NaOH} / \mathrm{FeCl}_{3}$ treated okara was stirred with $0.25 \mathrm{M} \mathrm{Zr}(\mathrm{IV})$ at the same conditions as mentioned above. After washing carefully with tap and then with distilled water to remove free $\operatorname{Zr}(\mathrm{IV})$ ions, the material was dried in the oven at $105^{\circ} \mathrm{C}$ for $24 \mathrm{~h}$ and cooled down to the room temperature.

\subsection{Experimental set-up}

The experimental set-up in this study is shown in Fig. 1 and described in detail as the follows:

\subsubsection{Adsorption studies}

The adsorption experiments were carried out with okara in the modified forms, as follows: $0.5 \mathrm{~g}$ of each metal loaded okara was taken into 9 conical flasks of $250 \mathrm{~mL}$ containing $50 \mathrm{ml}$ of different phosphorus solutions $(10,25,50,100,125,200,250,400$, $500 \mathrm{mg} \mathrm{P} / \mathrm{L}$ ). The $\mathrm{pH}$ of the solutions was kept natural. The samples were shaken at the speed of $120 \mathrm{rpm}$, room temperature, for $24 \mathrm{~h}$ to ensure the equilibrium could be fully reached. After the equilibrium time, the samples were filtered with Whatman ${ }^{\mathrm{TM}} 1822-047$ Grade GF/C filter paper (diameter: $4.7 \mathrm{~cm}$, pore size: $1.2 \mu \mathrm{m}$ ). The filtrate was taken for phosphorus determination. The phosphorus 


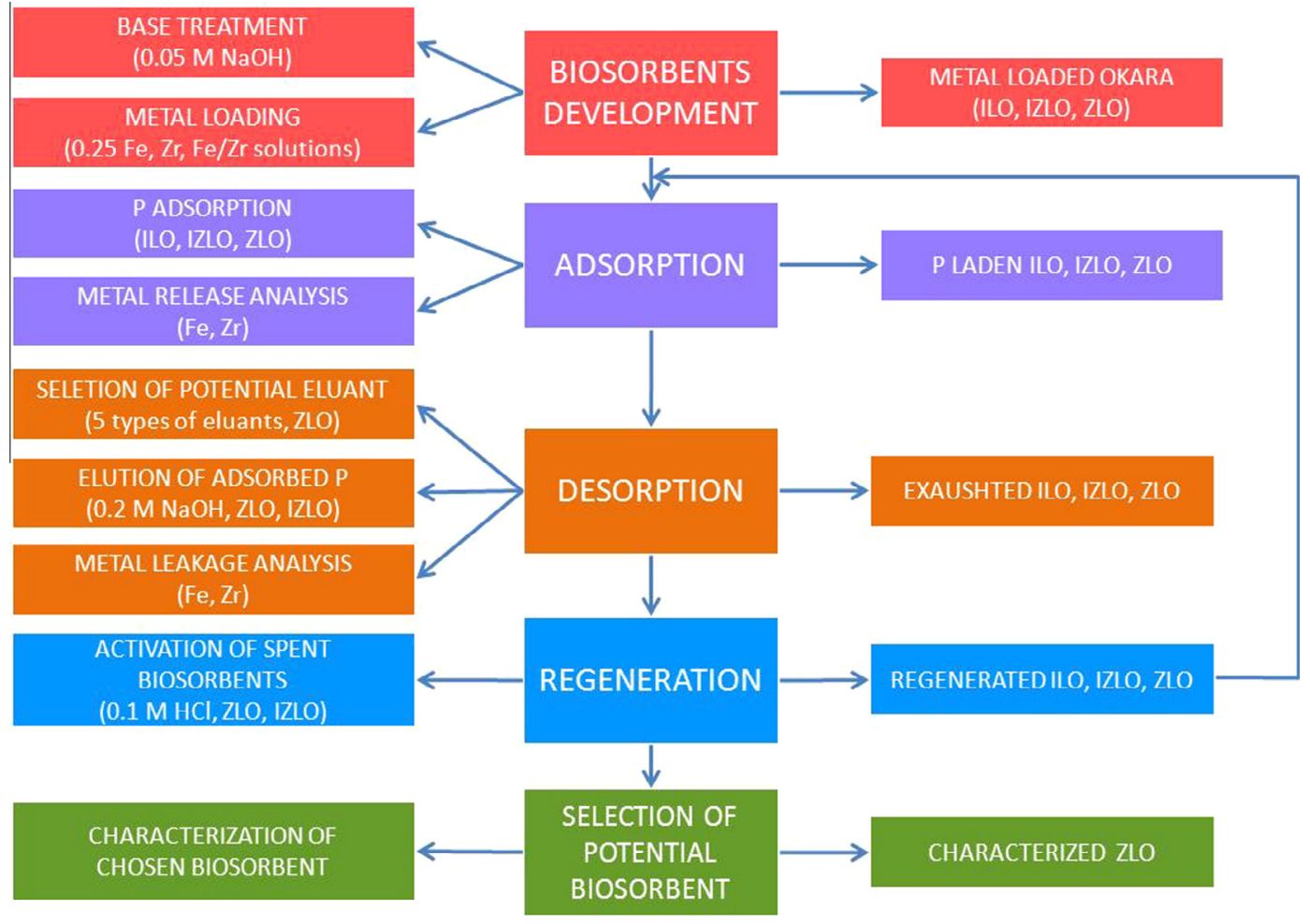

Fig. 1. Experimental set-up diagram.

adsorption capacity $(\mathrm{mg} / \mathrm{g})$ was calculated from the difference between initial and equilibrium phosphorus concentrations as follows:

$q=\frac{\left(C_{i}-C_{e}\right) * V}{m}$

where $C_{i}$ and $C_{e}$ are the initial and equilibrium phosphorus concentrations in the solution $(\mathrm{mg} / \mathrm{L})$, respectively; $V$ is the volume of the solution (L); and $m$ represents the dry weight of the metal loaded okara powder (g).

The adsorption equilibrium was investigated using Langmuir and Freudlich isotherms models.

\subsubsection{Desorption and regeneration studies}

After adsorption, the spent metal loaded okara ( $0.5 \mathrm{~g})$ as separated from the solution by filtration with Whatman ${ }^{\mathrm{TM}} 1822-047$ Grade GF/C filter paper (diameter: $4.7 \mathrm{~cm}$, pore size: $1.2 \mu \mathrm{m}$ ). The phosphorus bearing metal loaded okara was washed lightly with tap and then with distilled water to eliminate unadsorbed phosphorus. The solid was then collected into 5 conical flasks of $250 \mathrm{~mL}$, containing $50 \mathrm{ml}$ of 5 elution solutions (e.g. $0.2 \mathrm{M} \mathrm{NaOH}$, $0.05 \mathrm{M} \mathrm{NaOH}, \mathrm{pH} 12$ distilled water, $0.1 \mathrm{M} \mathrm{NaCl}$, and $0.1 \mathrm{M} \mathrm{HCl}$ ). All samples were agitated on an orbital shaker at the speed of $120 \mathrm{rpm}$, room temperature for $24 \mathrm{~h}$. After that time, the solid was removed from the solution by filtration again. The filtrates were used to evaluate the desorbed phosphorus amounts. Based on the desorption results, the potential eluant was identified and used for generation studies with both ZLO and IZLO.

After desorption with the potential eluant, the spent metal loaded okara were reused for other 4 continuous adsorptiondesorption cycles, with or without activation by $100 \mathrm{~mL}$ of $0.1 \mathrm{M}$ $\mathrm{HCl}$. The P removal percentage was used to determine the reusability of these two biosorbents.

\subsubsection{Identification of metal quantity deposited on okara}

The process to estimate the metal amounts deposited on okara was adapted from Boujelben et al. (2008). In this study, the treatment led to the dissolution of metals deposited on okara in concentrated nitric acid $\left(\mathrm{HNO}_{3}\right) .1 \mathrm{~g}$ of each biosorbent (e.g. ILO, IZLO, ZLO) was mixed at $50{ }^{\circ} \mathrm{C}$ with $10 \mathrm{~mL}$ of concentrated $\mathrm{HNO}_{3}(70 \%$, density $1.42 \mathrm{~g} / \mathrm{cm}^{3}$, molarity 15.8 ) and shook for $30 \mathrm{~min}$, and then with $20 \mathrm{~mL}$ of $0.1 \mathrm{M} \mathrm{HNO}_{3}$ and shook for $1 \mathrm{~h}$. After that, the suspension was filtered with Whatman ${ }^{\mathrm{TM}} 1822-047$ Grade GF/C filter paper (diameter: $4.7 \mathrm{~cm}$, pore size: $1.2 \mu \mathrm{m}$ ) for metal analysis.

\subsubsection{Determination of metal leakage during adsorption and desorption tests}

After adsorption and desorption, suspensions were filtered through Whatman ${ }^{\mathrm{TM}}$ 1822-047 Grade GF/C filter paper (diameter: $4.7 \mathrm{~cm}$, pore size: $1.2 \mu \mathrm{m}$ ). The filtrates were used to identify the metal concentrations.

\subsubsection{Determination of the content of phosphorus inside okara}

To identify the content of phosphorus inside okara, the authors have prepared samples according to the procedures described by Vietnam standards TCVN 8551:2010, Plants - Method for sampling and preparing sample, which was issued on 29 December 2010, at the Decision of 2945/QĐ-BKHCN. The concentration of phosphorus in the obtained solution was then determined spectrophotometrically by molybdenum blue method on Spectroquant ${ }^{\circledR}$ NOVA 60.

\subsubsection{Effect of co-anions on the removal of phosphorus by ZLO}

The influence of typical foreign anions, such as sulfate $\left(\mathrm{SO}_{4}^{2-}\right)$, nitrate $\left(\mathrm{NO}_{3}^{-}\right)$, chloride $\left(\mathrm{Cl}^{-}\right)$and carbonate $\left(\mathrm{CO}_{3}^{2-}\right)$ on the adsorption of phosphate $\left(\mathrm{PO}_{4}^{3-}\right)$ was investigated. The $\mathrm{KCl}, \mathrm{KNO}_{3}, \mathrm{~K}_{2} \mathrm{CO}_{3}$ and $\mathrm{Na}_{2} \mathrm{SO}_{4}$ salts were used to prepare the corresponding foreign anion solutions. $1 \mathrm{~g}$ of ZLO was added into a flask containing $50 \mathrm{~mL}$ of phosphorus solution, which was mixed with one foreign anion separately or four foreign anions simultaneously. The molar 
concentration of each foreign anion in the combined solution was 10 -fold higher than that of phosphorus. The experiment was performed at the initial phosphorus concentration of $100 \mathrm{mg} \mathrm{P} / \mathrm{L}$ $\left(\sim 3 \mathrm{mmol} \mathrm{PO}_{4} / \mathrm{L}\right)$, original $\mathrm{pH}, 25^{\circ} \mathrm{C}$, and agitation speed of $120 \mathrm{rpm}$ for $24 \mathrm{~h}$, in the presence of single or multi foreign anions. The control experiment was conducted at the same conditions, in the absence of foreign anions.

\subsection{Analytical methods}

\subsubsection{Determination of phosphorus content in the solution}

Phosphorus concentrations of the solutions before and after adsorption were determined spectrophotometrically using molybdenum blue method on Spectroquant ${ }^{\circledR}$ NOVA 60. Experiments were implemented in triplicate and the data represented the mean values. The highest acceptable deviation was $5 \%$.

\subsubsection{Identification of metal concentration in the solution}

The concentration of metals released into the solution during adsorption and desorption tests was measured using Microwave Plasma-Atomic Emission Spectrometer (MP-AES) - Agilent Technologies 4100 .

\subsubsection{Physical characteristics of the chosen metal loaded okara (ZLO)}

This study investigates such physical characteristics of ZLO as density, porosity, and permeability. The density and porosity of ZLO were determined using procedures outlined by Okochi (2013). The permeability coefficient of ZLO was determined using Darcy's Law (http://www.ajdesigner.com/phppermeameter/permeameter_equation_permeability_coefficient.php). The experiment design is illustrated in Fig. 2.

$K=\frac{Q \Delta L}{A \Delta h}$

where $K$ is the permeability coefficient ( $\mathrm{m} /$ day) $Q$ is the porous medium flow rate $\left(\mathrm{m}^{3} / \mathrm{s}\right), \Delta L$ is the length change $(\mathrm{m}), A$ is the cross sectional area $\left(\mathrm{m}^{2}\right), \Delta H$ is the pressure head change $(\mathrm{m})$.

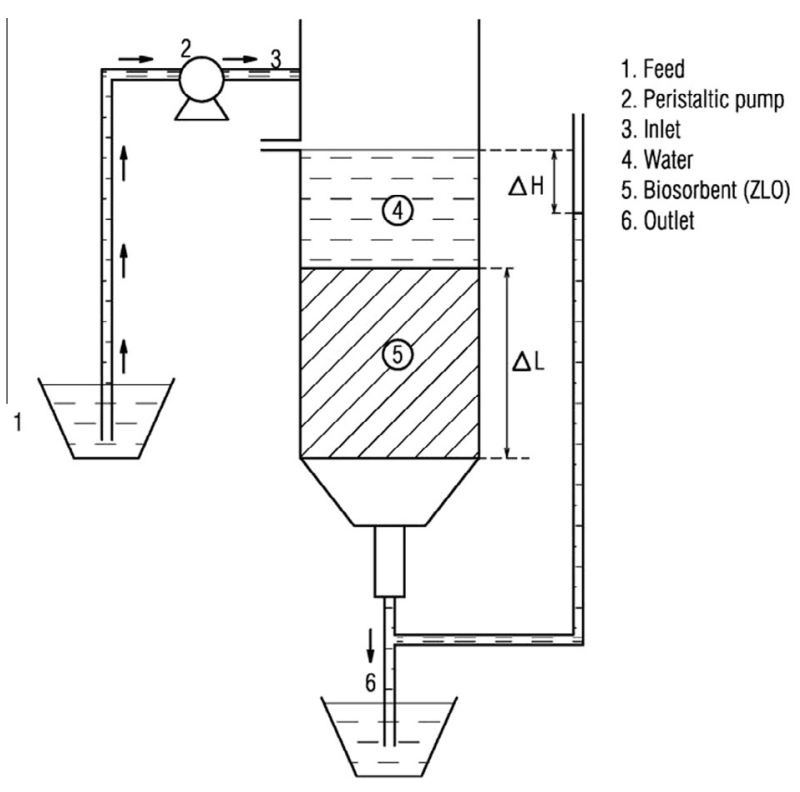

Fig. 2. Experimental design to determine the permeability coefficient of ZLO.

\section{Results and discussion}

\subsection{Adsorption isotherm}

Equilibrium studies are essential to determine the adsorption capacity of ZLO, IZLO and ILO. The initial phosphorus concentration used in this study was in the range of $10-500 \mathrm{mg} / \mathrm{L}$. The isotherm data was analyzed using two of the most widely used equilibrium models, Langmuir and Freundlich. The linear expressions of Langmuir and Freundlich isotherms are given as follows (Krishnan and Haridas, 2008):

$$
\begin{aligned}
& \frac{C_{e}}{q_{e}}=\frac{1}{K_{L} q_{m}}+\frac{C_{e}}{q_{m}} \\
& \ln q_{e}=\ln K_{F}+\frac{1}{n} \ln C_{e}
\end{aligned}
$$

where $q_{e}$ is the amount of phosphorus adsorbed per unit weight of biosorbent $(\mathrm{mg} / \mathrm{g}), C_{e}$ is the equilibrium phosphorus concentration $(\mathrm{mg} / \mathrm{L}), q_{m}$ and $K_{L}$ are Langmuir constants, representing the maximum adsorption capacity $(\mathrm{mg} / \mathrm{g}$ ) of the biosorbent when all available adsorption sites are occupied and affinity of binding sites (L/mg), $K_{F}$ and $n$ are Freundlich constants, relevant to adsorption capacity and adsorption intensity, respectively.

The Langmuir and Freundlich constants were determined by linear regression method, from linear plots of $C_{e} / q_{e}$ versus $C_{e}$ and $\ln q_{e}$ versus $\ln C_{e}$, respectively. The results are shown in Table 1 . It is clear that, both isotherm models represented well the experimental data, with $R^{2}$ values were higher than 0.9. However, Langmuir model provided a better fit with isotherm data of ILO than Freundlich model. This indicated that the sorption of $\mathrm{PO}_{4}^{3-}$ by ILO was probably monolayer and the surface of ILO could be homogenous. On the other hand, Freundlich model was more efficient than Langmuir model in describing isotherm data for the sorption of $\mathrm{PO}_{4}^{3-}$ anions on both IZLO and ZLO. This finding revealed that the surface of IZLO and ZLO might be heterogeneous. In addition, there was a possibility of formation of multi layers on their surface during adsorption processes. In all cases, it was found that $n>1$, implying the biosorption of $\mathrm{PO}_{4}^{3-}$ by ILO, IZLO, ZLO was favorable (de Lima et al., 2012).

By comparing the maximum adsorption capacity of $\mathrm{PO}_{4}^{3-}$ anions, ZLO $(47.88 \mathrm{mg} / \mathrm{g})$ was found to be superior to IZLO $(40.86 \mathrm{mg} / \mathrm{g})$ and ILO $(16.39 \mathrm{mg} / \mathrm{g})$. Table 2 summarizes the maximum adsorption capacity of various biosorbents for the comparison purpose. It was found that IZLO and ZLO exhibited remarkable affinities towards $\mathrm{PO}_{4}^{3-}$, which are favorably comparable with the majority of biosorbents reported in literature. Comparing with natural okara $\left(2.45 \mathrm{mg} \mathrm{PO}_{4} / \mathrm{g}\right)$, the phosphorus sorption capacities of ZLO and IZLO were boosted nearly $95 \%$. The results proved that metal loading was an efficient method in enhancing the $\mathrm{PO}_{4}^{3-}$ sequestering ability of original okara. Biswas et al. $(2008,2007)$ claimed that, the adsorption of phosphate by metal loaded AWBs based biosorbents were possibly due to the ligand exchange mechanism, which occurred between $\mathrm{PO}_{4}^{3-}$ ions in the solution and $\mathrm{OH}^{-}$ions coordinated with the metal ions loaded on AWBs based biosorbents. They suggested that, loaded metal ions could be easily converted into hydrated forms e.g. $\left[\mathrm{Ln}\left(\mathrm{H}_{2} \mathrm{O}\right)_{\mathrm{n}}\right]^{3+},\left[\mathrm{Zr}_{4}(\mathrm{OH})_{8}\left(\mathrm{H}_{2} \mathrm{O}\right)_{16}\right]^{8+}$, and $\left[\mathrm{Zr}_{8}(\mathrm{OH})_{20}\left(\mathrm{H}_{2} \mathrm{O}\right)_{24}\right]^{12+}$ species, with the abundant amounts of $\mathrm{OH}^{-}$ions and $\mathrm{H}_{2} \mathrm{O}$ molecules. During the hydrolysis, $\mathrm{H}_{2} \mathrm{O}$ molecules were deprotonated by releasing $\mathrm{H}^{+}$ions to form exchangeable $\mathrm{OH}^{-}$ions, which could be replaced by $\mathrm{PO}_{4}^{3-}$ ions via ligand exchange mechanism. As can be seen from Table 2, $\mathrm{q}_{m}$ values of diverse biosorbents were reported at the operating conditions, which were different from those used for this study. Specifically, larger initial $\mathrm{PO}_{4}^{3-}$ concentration range was used by De Lima et al. (2012), lower pH values were used by 
Table 1

Langmuir and Freundlich parameters for adsorption of $\mathrm{PO}_{4}^{3-}$ on ILO, IZLO, ZLO.

\begin{tabular}{|c|c|c|c|c|c|c|}
\hline \multirow[t]{2}{*}{ Biosorbents } & \multicolumn{3}{|c|}{ Langmuir constants } & \multicolumn{3}{|l|}{ Freudlich constants } \\
\hline & $q_{m}\left(\mathrm{mg} \mathrm{PO}_{4} / \mathrm{g}\right)$ & $K_{L}(\mathrm{~L} / \mathrm{mg})$ & $R^{2}$ & $K_{F} \mathrm{mg} / \mathrm{g}(\mathrm{L} / \mathrm{mg})^{1 / n}$ & $n$ & $R^{2}$ \\
\hline ILO & 16.39 & 0.11 & 0.99 & 5.18 & 4.74 & 0.92 \\
\hline IZLO & 40.86 & 0.04 & 0.96 & 11.48 & 4.98 & 0.97 \\
\hline ZLO & 47.88 & 0.06 & 0.97 & 11.56 & 4.02 & 0.97 \\
\hline
\end{tabular}

Table 2

Comparison of ILO, IZLO, ZLO and various biosorbents reported in the literature, in term of the maximum $\mathrm{PO}_{4}^{3-}$ adsorption capacity.

\begin{tabular}{|c|c|c|c|c|c|}
\hline Biosorbents & $\begin{array}{l}\mathrm{PO}_{4}^{3-} \text { concentration } \\
\text { range }(\mathrm{mg} / \mathrm{L})\end{array}$ & $\mathrm{pH}$ & $\begin{array}{l}\text { Biosorbent } \\
\text { dose }(\mathrm{g} / \mathrm{L})\end{array}$ & $\begin{array}{l}\text { Maximum adsorption } \\
\text { capacity }\left(\mathrm{mg} \mathrm{PO}_{4} / \mathrm{g}\right)\end{array}$ & Reference \\
\hline $\begin{array}{l}\text { Carboxymethyl cellulose/Fe(II) treated aspen } \\
\text { wood fiber }\end{array}$ & - & 4.8 & 2 & 4.3 & Eberhardt et al. (2006) \\
\hline $\mathrm{Zn}(\mathrm{II})$ activated coir pith carbon & $10-40$ & $3-10$ & 6 & 5.10 & $\begin{array}{l}\text { Namasivayam and } \\
\text { Sangeetha (2004) }\end{array}$ \\
\hline Acid mine drainage treated juniper fiber & 30.64 & 6.4 & $2-20$ & 7.08 & Han et al. (2005) \\
\hline Iron hydroxide eggshell & $7-140$ & 7.0 & 7.5 & 14.49 & $\begin{array}{l}\text { Mezenner and Bensmaili } \\
\text { (2009) }\end{array}$ \\
\hline Fe(III) loaded okara & 10-500 & $7.60-7.8$ & 10 & 16.39 & Present study \\
\hline Wood modified by carboxymethyl cellulose $/ \mathrm{FeCl}_{2}$ & $0-100$ & & 4 & 17.38 & $\begin{array}{l}\text { Eberhardt and Min } \\
\text { (2008) }\end{array}$ \\
\hline $\mathrm{Zr}$ (IV) loaded apple peels & $5-200$ & $2-6$ & 10 & 20.35 & $\begin{array}{l}\text { Mallampati and } \\
\text { Valiyaveettil (2013) }\end{array}$ \\
\hline $\mathrm{Al}(\mathrm{III})$ loaded skin plit waste & $47.5-285$ & 7.0 & 1 & 21.65 & Huang et al. (2009) \\
\hline Cationized wood & - & $3.0-9.0$ & - & 25.65 & Karthikeyan et al. (2004) \\
\hline $\begin{array}{l}\text { Fe(III) loaded carboxylated polyacrylamide - } \\
\quad \text { grafted sawdust }\end{array}$ & $9.50-23.75$ & 2.5 & 2 & 28.79 & Unnithan et al. (2001) \\
\hline $\mathrm{Fe}(\mathrm{III}) / \mathrm{Zr}$ (IV) loaded okara & 10-500 & 7.6-7.8 & 10 & 40.86 & Present study \\
\hline Cationized bark & - & $3.0-9.0$ & - & 44.65 & Karthikeyan et al. (2004) \\
\hline Zr(IV) loaded okara & $10-500$ & $7.6-7.8$ & 10 & 47.88 & Present study \\
\hline $\mathrm{Fe}(\mathrm{III})$ loaded skin split waste & $47.5-285$ & 7.0 & 1 & 72 & Huang et al. (2009) \\
\hline $\mathrm{Fe}(\mathrm{III})$ impregnated coir pith & $20-200$ & 3.0 & 2 & 70.92 & $\begin{array}{l}\text { Krishnan and Haridas } \\
(2008)\end{array}$ \\
\hline $\begin{array}{l}\text { Bagasse fiber carboxymethylated on surface and } \\
\text { doped with } \mathrm{FeCl}_{2} \text { ions }\end{array}$ & $2-10$ & - & - & 152 & Carvalho et al. (2011) \\
\hline $\mathrm{Zr}(\mathrm{IV})$ loaded orange waste gels & & 7.0 & 1.67 & 175 & Biswas et al. (2008) \\
\hline Coconut shell fibers & $20-1000$ & & 10 & 200 & De Lima et al. (2012) \\
\hline
\end{tabular}

Eberhardt et al. (2006), Krishnan and Haridas (2008), Mallampati and Valiyaveettil (2013), and higher dose of biosorbents was found in a research by Han et al. (2005). These results suggested that $q_{m}$ values of three kinds of metal loaded okara in this study could be further improved by optimizing the adsorption conditions. This was strongly supported by Fig. 3, which displayed that the curves of IZLO and ZLO did not reach a constant in the investigated range of phosphorus concentration. Thus, for better comparison of the sorption capacity among biosorbents, $\mathrm{q}_{m}$ values at the optimum adsorption conditions should be determined and applied.

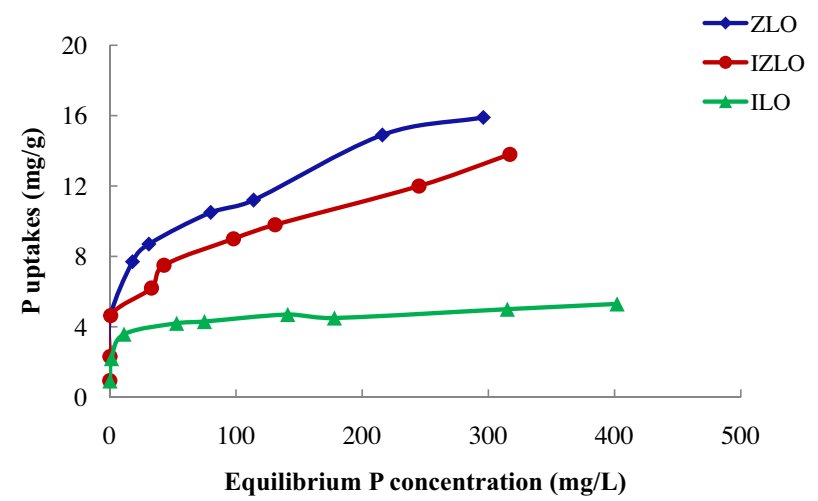

Fig. 3. Isotherm of phosphorus adsorption by ILO, IZLO, ZLO ( $T=298 \mathrm{~K}, t=24 \mathrm{~h}$, shaking speed $=120 \mathrm{rpm}, C_{i}=50 \mathrm{mg} / \mathrm{L}$, dose $\left.=10 \mathrm{~g} / \mathrm{L}, \mathrm{pH} 7-7.5\right)$.

\subsection{Desorption of phosphorus and biosorbents reusability}

Desorption of phosphorus paves the way to the recovery of this non-renewable resource, while reuse of a biosorbent gives a chance to reduce the cost of water treatment and to mitigate adverse impacts on the environment. For those reasons, desorbability and reusability of a biosorbent are very important to its applicability and need to be investigated in detail. Five solutions of $0.2 \mathrm{M} \mathrm{NaOH}, 0.05 \mathrm{M} \mathrm{NaOH}, \mathrm{pH} 12$ distilled water, $0.1 \mathrm{M} \mathrm{HCl}$, and $0.1 \mathrm{M} \mathrm{NaCl}$ were evaluated for the elution of phosphorus from ZLO. The extremely low desorption percentage $(<1 \%)$ for phosphorus was found with both $0.1 \mathrm{M} \mathrm{HCl}$ and $0.1 \mathrm{M} \mathrm{NaCl}$ solutions. Higher desorption efficiencies were achieved with $\mathrm{pH} 12$ distilled water (49.45\%) and $0.05 \mathrm{M} \mathrm{NaOH}$ (70.76\%). Among various eluants employed, $0.2 \mathrm{M} \mathrm{NaOH}$ was found to be most efficient, with the elution efficiency reached up to $97.8 \%$. This can be explained by the replacement of $\mathrm{PO}_{4}^{3-}$ anions bound to the $\mathrm{ZLO}$ by $\mathrm{OH}^{-}$ions during desorption process. Also, the desorption results revealed that ion exchange might be an important mechanism in the adsorption of $\mathrm{PO}_{4}^{3-}$ by $\mathrm{ZLO}$. This finding was in consistent with a previous study conducted by Unnithan et al. (2001), reporting that desorption efficiency of $96.8 \%$ could be achieved with $0.1 \mathrm{M} \mathrm{NaOH}$.

Due to the satisfactory desorption result, $0.2 \mathrm{M} \mathrm{NaOH}$ was employed as a potential eluant in the following regeneration study with ZLO and IZLO. Fig. 4 displays the results of five continuous adsorption-desorption cycles obtained with ZLO and IZLO, which were activated by $0.1 \mathrm{M} \mathrm{HCl}$ after desorption with $0.2 \mathrm{M} \mathrm{NaOH}$. Surprisingly, the phosphorus removal efficiency of both ZLO and 


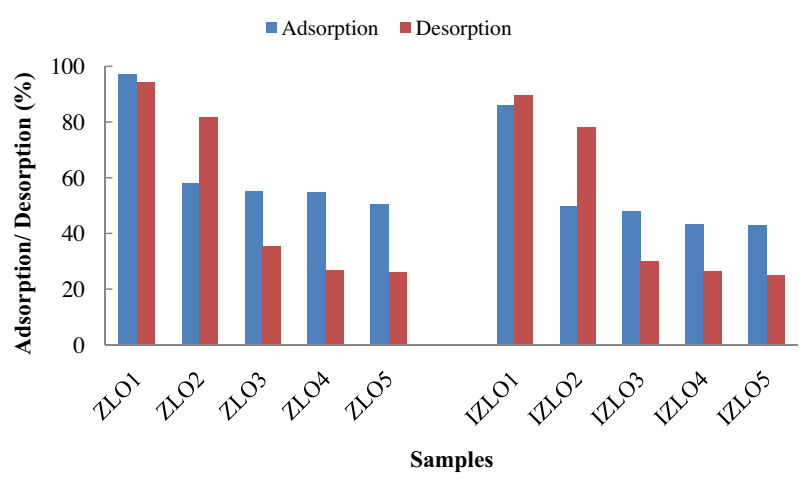

Fig. 4. The phosphorus adsorption and desorption efficiency obtained with ZLO and IZLO in 5 consecutive cycles $\left(T=298 \mathrm{~K}, t=24 \mathrm{~h}\right.$, shaking speed $=120 \mathrm{rpm}, C_{i}=50$ $\mathrm{mg} / \mathrm{L}$, dose $=10 \mathrm{~g} / \mathrm{L}, \mathrm{pH} 7-7.5)$.

IZLO dropped dramatically in the second cycle and stayed almost the same in the next cycles. After five cycles, the phosphorus removal efficiency reduced by $46.74 \%$, while the phosphorus desorption efficiency decreased by $68.30 \%$ for ZLO. The corresponding values for IZLO were $42.93 \%$ and $64.83 \%$. The desorption efficiency of ZLO and IZLO in the fifth cycle was just around 25\%, which was too low for any application. $\mathrm{pH}$ values of solutions after adsorption from the second cycle on were found to be above 10 . The results suggested that, the low phosphorus removal efficiency mentioned above was possibly due to high $\mathrm{pH}$ values, which hindered the capture of $\mathrm{PO}_{4}^{3-}$ anions. This assumption was tested by conducting other adsorption experiments with $0.1 \mathrm{M} \mathrm{HCl}$ activated ZLO and IZLO. The results were depicted in Fig. 5.

After five cycles, the phosphorus removal efficiency of ZLO was reduced by $12.46 \%$, whereas phosphorus desorption percentage only decreased by $7.40 \%$. The corresponding values for IZLO were $21.91 \%$ and $17.45 \%$. Evidently, activation of ZLO, IZLO with $100 \mathrm{~mL}$ of $0.1 \mathrm{M} \mathrm{HCl}$ resulted in more satisfying adsorption and desorption efficiencies. The $\mathrm{pH}$ values of the solutions after adsorption using $0.1 \mathrm{M} \mathrm{HCl}$ activated ZLO and IZLO were around 7.5. Comparing $\mathrm{pH}$ values and adsorption efficiencies obtained with ZLO, IZLO and those achieved with $0.1 \mathrm{M} \mathrm{HCl}$ activated IZLO, ZLO confirmed the hypothesis that, using $0.2 \mathrm{M} \mathrm{NaOH}$ for elution led to an increase in the $\mathrm{pH}$ values of adsorption solutions in the next cycle. Due to the unfavorable $\mathrm{pH}$ medium, the uptake of $\mathrm{PO}_{4}^{3-}$ in the next cycle was sharply declined. It would therefore appear that, $0.2 \mathrm{M} \mathrm{NaOH}$ is appropriate for long-term desorption of phosphorus from ZLO and IZLO if the desorbed biosorbents are activated with $0.1 \mathrm{M} \mathrm{HCl}$ before next adsorption cycle. The phosphorus adsorption and desorption efficiencies of ZLO remained about $85 \%$ after five

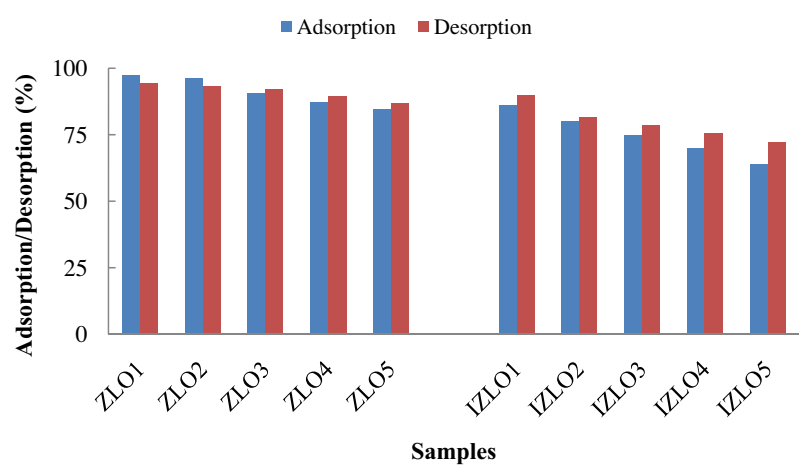

Fig. 5. The phosphorus adsorption and desorption efficiency obtained with $0.1 \mathrm{M}$ $\mathrm{HCl}$ activated ZLO and IZLO in 5 consecutive cycles $(T=298 \mathrm{~K}, t=24 \mathrm{~h}$, shaking speed $=120 \mathrm{rpm}, C_{i}=50 \mathrm{mg} / \mathrm{L}$, dose $\left.=10 \mathrm{~g} / \mathrm{L}, \mathrm{pH} 7-7.5\right)$. consecutive adsorption-desorption cycles. This indicates the high reusability of ZLO for phosphorus decontamination. Significant decline in the adsorption and desorption efficiencies of IZLO (21.91\% and $17.45 \%$ ) after five continuous operation cycles might prevent this biosorbent from being reused.

\subsection{Metal deposition on okara and metal release into aqueous solutions during adsorption and desorption tests}

The $\mathrm{PO}_{4}^{3-}$ retention ability of a biosorbent is largely depends on the existence of loading metals on its surface (Carvalho et al., 2011). Thus, the loaded metal content exhibits not only the affinity of okara toward the metal, but also the $\mathrm{PO}_{4}^{3-}$ sorption capacity of that metal loaded okara. Table 3 represents data on metal deposition on okara and metal release into aqueous solutions during the performance of metal loaded okara. Table 3 shows that, 1 gram of natural okara was saturated with $21.62 \mathrm{mg}$ of Fe(III) but $40.44 \mathrm{mg}$ of $\mathrm{Zr}(\mathrm{IV})$, indicating the higher affinity of phosphorus toward $\mathrm{Zr}(\mathrm{IV})$ as compared to $\mathrm{Fe}(\mathrm{III})$. Based on the ratio of absorbed phosphorus to loaded metal, $\mathrm{Zr}$ (IV) was found to have a higher affinity toward $\mathrm{PO}_{4}^{3-}$ than $\mathrm{Fe}(\mathrm{III})$. The amount of $\mathrm{Fe}(\mathrm{III})$ deposited on IZLO accounted for only $8.79 \%$ of that on ILO. This indicated that a significant amount of $\mathrm{Fe}$ (III) was leaked during the pretreatment of ILO with $\mathrm{Zr}(\mathrm{IV})$ to produce IZLO. Simultaneously, some Fe(III) ions on ILO was probably replaced by $\mathrm{Zr}(\mathrm{IV})$ ions in the loading solution. The presence of $\mathrm{Fe}(\mathrm{III})$ on IZLO resulted in a reduction of $6.70 \%$ the amount of $\mathrm{Zr}$ (IV) used for okara loading as compared to ZLO. However, it should also be noted that the phosphorus uptake capacity of IZLO was $14.72 \%$ lower than that of ZLO. The results indicate that loading okara with combined $\mathrm{Fe}(\mathrm{III}) / \mathrm{Zr}$ (IV) solutions was not superior to doing that with single $\mathrm{Zr}(\mathrm{IV})$ solution. $\mathrm{Fe}(\mathrm{III})$ accounted for only $4.79 \%$ of the total amount of metals loaded on okara. Also, the affinity of $\mathrm{Fe}(\mathrm{III})$ toward $\mathrm{PO}_{4}^{3-}$ was inferior to $\mathrm{Zr}(\mathrm{IV}$ ) as mentioned above. Evidently, $\mathrm{Fe}(\mathrm{III})$ played a less important role than $\mathrm{Zr}(\mathrm{IV})$ in the capture of $\mathrm{PO}_{4}^{3-}$ by IZLO, in term of both the quantity and the affinity.

The leakage of metals deposited on okara is a critical indicator for the unstability of the metal loaded okara. Tables 3 indicates that when ZLO was used for phosphorus removal, the content of $\mathrm{Zr}(\mathrm{IV})$ in the samples after adsorption and desorption processes was not detected. This provides strong evidence that ZLO is a stable biosorbent. Similar observation was noticed for $\mathrm{Zr}(\mathrm{IV})$ in case of IZLO. The results were in harmony with those in earlier studies (Biswas et al., 2008; Mallampati and Valiyaveettil, 2013), reporting that $\mathrm{Zr}(\mathrm{IV})$ could hardly be detached during its performance. On the other hand, in case of IZLO and ILO, the release of Fe(III) during adsorption process was significant, with $0.54 \mathrm{mg} / \mathrm{g}$ from IZLO and $1.59 \mathrm{mg} / \mathrm{g}$ from ILO. The latter value was in the same order of magnitude, when compared with $1.65 \mathrm{mg} / \mathrm{g}$ previously reported for wood particle treated with carboxymethyl cellulose and ferrous chloride (Eberhardt and Min, 2008). Taking into account the obtained results, it could be concluded that ZLO had the highest stability, followed by IZLO and ILO.

The metal leakage may cause adverse impacts on the aquatic medium if metals are toxic and their concentrations exceed the permissible levels. ForZrOCl , the fish toxicity (LC50) was found to be 15-270 mg Zr/L (Bluegill, Fathead minnow, $96 \mathrm{~h}$ ) (Morning Star Consulting Inc., 2005). In case of $\mathrm{FeCl}_{3}$, the fish toxicity (LC50) was $92.8 \mathrm{mg} / \mathrm{L}$ (Brachydanio rerio, $48 \mathrm{~h}$ ), $75.6 \mathrm{mg} / \mathrm{L}$ (Gambusia affinis, $96 \mathrm{~h}$ ), $117 \mathrm{mg} / \mathrm{L}$ (Poecilia reticulata, 48 h), $23 \mathrm{mg} / \mathrm{L}$ (Oryzias latipes $48 \mathrm{~h}$ ) (http://www.thamesriverchemical.com/safetysheets/ Ferric\%20Chloride40solution.pdf). In this study, the highest concentrations of $\mathrm{Zr}(\mathrm{IV})$ and $\mathrm{Fe}(\mathrm{III})$ in aqueous solutions were found to be 0 and $12 \mathrm{mg} / \mathrm{L}$, respectively. These values are far too low as compared to LC50 values mentioned above. This convinces that, 


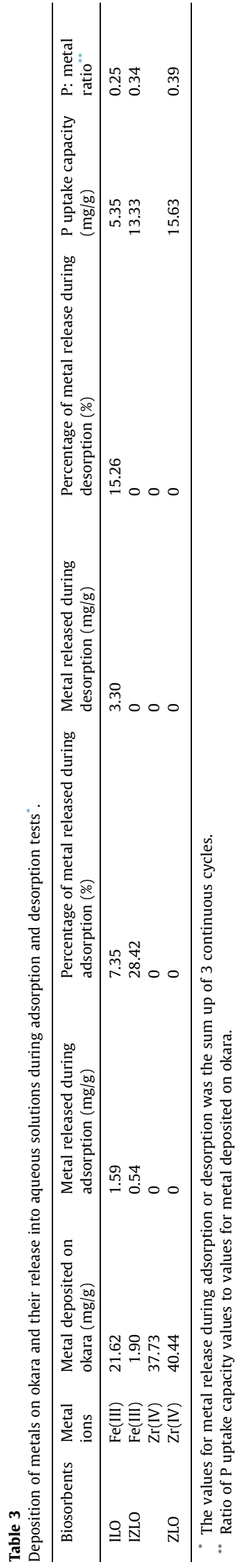

the use of ILO, IZLO, ZLO as biosorbents of phosphorus cannot pose any risk to aquatic creatures.

\subsection{Selection of the most suitable biosorbent for further investigation}

ZLO offered the highest adsorption capacity ( $47.88 \mathrm{mg} / \mathrm{g}$ ), which was equal or even better than several biosorbents reported in literature. Due to the high stability, ZLO can be used repeatedly without the necessity of metal reloading. Furthermore, the experimental data showed that ZLO could be recycled at least five times without a significant reduction in the phosphorus removal efficiency. Thus, ZLO can be a cost-effective biosorbent. Moreover, ZLO did not cause any harmful effects on the aquatic medium. Conversely, the use of IZLO and ILO for biosorption of phosphorus suffered from trivial limitations, such as notable metal leakage, fast drop in phosphorus removal efficiency after several cycles. Apparently, among three biosorbents investigated in this study, ZLO was the best choice for the elimination of phosphorus from aqueous solutions.

The applicability of ZLO not only depends on the adsorption capacity, desorption ability and reusability, but also the physical characteristics of the material. Thus, the present study examined such physical properties as density, porosity and permeability of ZLO. It was found that, ZLO (particle size range of $400-650 \mu \mathrm{m}$ ) has the bulk density of $0.36 \mathrm{~g} / \mathrm{cm}^{3}$, porosity of $50 \%$, and permeability coefficient of $0.0079 \mathrm{~m} / \mathrm{s}$. Due to the low density and high porosity, ZLO is appropriate for being applied in up-flow column mode experiments. The initial investigation indicated that, ZLO can also be used in down-flow column mode experiments. These features should enhance the practical application of ZLO.

In the real wastewater, many anions may exist and thus competing with phosphate for anion binding sites on the adsorbents. Therefore, to evaluate the practical applicability of ZLO, the current study examined the phosphate removal of ZLO from synthetic wastewater, in the addition of individual or collective foreign anions. It was revealed that, addition of 10 -fold higher molar concentrations of carbonate largely reduced the phosphate retention (23.52\%), whilst sulfate, nitrate, chloride hardly interfered with the phosphate decontamination. The competing effect of carbonate can be ascribed to the higher affinity between ZLO and carbonate, when compared to that between ZLO and phosphate. However, this effect can be eliminated by conversion of dissolved carbonate salts into precipitated carbonate salts or gas carbon dioxide prior to the phosphate adsorption. The minimum interference of sulfate, nitrate and chloride can also be detected in the work conducted by Biswas et al. (2008, 2007); Jyothi et al. (2012). The results specify the potential of employing ZLO for the treatment of phosphate in the real wastewater.

\section{Conclusion}

ZLO proved to be superior to IZLO and ILO, with respect to adsorption, desorption and reusability. ZLO exhibited a relatively high phosphate adsorption capacity. Successful phosphate elution from spent ZLO was achieved with $0.2 \mathrm{M} \mathrm{NaOH}$. By activation with $0.1 \mathrm{M} \mathrm{HCl}$, ZLO could work proficiently for at least five consecutive cycles. The presence of common anions (e.g. sulfate, nitrate and chloride) hardly interfered with the performance of ZLO. The physical properties of ZLO favored its application in the column mode. Conclusively, ZLO can be used as a promising biosorbent for the treatment of phosphorus from aqueous solutions.

\section{Acknowledgements}

This study was supported by Sustainable Water Group, Centre for Technology in Water and Wastewater (CTWW), School of Civil 
and Environmental Engineering, University of Technology, Sydney (UTS). The first author is also thankful to Australian Government for granting her Australian Awards scholarship.

\section{References}

Adachi, A., Hanamoto, H. Okanano, T. 2005. Use of lees materials as an adsorbent for removal of organochlorine compounds or benzene from wastewater. Chemosphere 58, 817-822.

Anirudhan, T.S., Noelin, B.F., Manohar, D.M., 2006. Phosphate removal from wastewaters using a weak anion exchanger prepared from a lignocellulosic residue. Environ. Sci. Technol. 40, 2740-2745.

Benyoucef, S., Amrani, M., 2011. Adsorption of phosphate ions onto low cost Aleppo pine adsorbent. Desalination 275, 231-236.

Bhojappa, S., 2009. Removal of Phosphorus and Selenium from Aqueous Solution by Adsorption Processes (Master Thesis). West Virginia University, Morgantown, West Virginia, USA.

Biswas, B.K., Inoue, K., Ghimire, K.N., Ohta, S., Harada, H., Ohto, K., Kawakita, H., 2007. The adsorption of phosphate from an aquatic environment using metal loaded orange waste. J. Colloid Interface Sci. 312, 214-223.

Biswas, B.K. Inoue, K., Ghimire, K.N., Harada, H., Ohto, K., Kawakita, H., 2008. Removal and recovery of phosphorus from water by means of adsorption onto orange waste gel loaded with zirconium. Bioresour. Technol. 99, 8685-8690.

Boujelben, N., Bouzid, J., Elouear, Z., Feki, M., Jamoussi, F., Montiel, A., 2008. Phosphorus removal from aqueous solution using iron coated natural and engineered sorbents. J. Hazard. Mater. 151, 103-110.

Carvalho, W.S., Martins, D.F., Gomes, F.R., Leite, I.R., Gustavo da Silva, L., Ruggiero, R., Richter, E.M., 2011. Phosphate adsorption on chemically modified sugarcane bagasse fibers. Biomass Bioenergy 35, 3913-3919.

De Lima, A.C.A., Nascimento, R.F., de Sousa, F.F., Filho, J.M., 2012. Modified coconut shell fibers: a green and economical sorbent for the removal of anions from aqueous solutions. Chem. Eng. J., 185-186, 274-284.

Eberhardt, T.L., Min, S.H., 2008. Biosorbents prepared from wood particles treated with anionic polymer and iron salt: effect of particle size on phosphate adsorption. Bioresour. Technol. 99, 626-630.

Eberhardt, T.L., Min, S.H., Han, J.S., 2006. Phosphate removal by refined aspen wood fiber treated with carboxymethyl cellulose and ferrous chloride. Bioresour. Technol. 97, 2371-2376.

Eljamal, O., Okawauchi, J., Hiramatsu, K., Harada, M., 2013. Phosphorus sorption from aqueous solution using natural materials. Environ. Earth Sci. 68, 859-863.

Han, J.S., Min, S.H., Kim, Y.K., 2005. Removal of phosphorus using AMD treated lignocellulosic material. Forest Prod. J. 55, 48-53.

Huang, X., Liao, X., Shi, B., 2009. Adsorption removal of phosphate in industrial wastewater by using metal loaded skin split waste. J. Hazard. Mater. 166, $1261-$ 1265.

Ismail, Z.Z., 2012. Kinetic study for phosphate removal from water by recycled date - palm wastes as agricultural by-products. Int. J. Environ. Stud. 69, 135-149.

Jyothi, M.D., Kiran, K.R., Ravindhranath, K., 2012. Phosphate pollution control in waste waters using new biosorbents. Int. J. Water Resour. Environ. Eng. 4, 7385.
Kalmykova, Y., Fedje, K., 2013. Phosphorus recovery from municipal solid waste incineration fly ash. Waste Manage. 33, 1403-1410.

Karthikeyan, K.G., Tshabalala, M.A., Wang, D., Kalbasi, M., 2004. Solution chemistry effects on orthophosphate adsorption by cationized solid wood residues. Environ. Sci. Technol. 38, 904-911.

Krishnan, K.A., Haridas, A., 2008. Removal of phosphate from aqueous solutions and sewage using natural and surface modified coir pith. J. Hazard. Mater. 152, $527-$ 535.

Li, L., 2009. Adsorption of Cd(II) and Zn(II) from Aqueous Solutions by Raw Bean Dregs (Master thesis). College of Environmental Science and Engineering, Human University, China. <http://Globalthesis.com/>.

Li, Y.J., Wang, L.H., Lan, Y.Z., 2009. Experimental study on phosphorus removal by activated alumina adsorbents. J. Kunming Metall. Coll. 25, 59-65.

Li, B., Qiao, M., Lu, F., 2012. Composition, nutrition, and utilization of okara (soybean residue). Food Rev. Int. 28, 231-252.

Loganathan, P., Vigneswaran, S., Kandasamy, J., Bolan, N.S., 2013. Removal and recovery of phosphate from water using sorption. Crit. Rev. Environ. Sci. Technol.. http://dx.doi.org/10.1080/10643389.2012.741311.

Mallampati, R., Valiyaveettil, S., 2013. Apple peels - a versatile biomass for water purification? ACS Appl. Mater. Interfaces 5, 4443-4449.

Marshall, W.E., Wartelle, L.H., 2004. An anion exchange resin from soybean hulls. J. Chem. Technol. Biotechnol. 79, 1286-1292.

Mezenner, N.Y., Bensmaili, A., 2009. Kinetics and thermodynamic study of phosphate adsorption on iron hydroxide-eggshell waste. Chem. Eng. J. 147, 87-96.

Morning Star Consulting Inc, 2005. Summary of existing data, proposed test plan and rationale for hexanoic acid, 2-ethyl, zirconium salt (CAS RN 22464-99-9). U.S. High production volume (HPV). Chemical challenge program.

Namasivayam, C., Sangeetha, D., 2004. Equilibrium and kinetic studies of adsorption of phosphate onto $\mathrm{ZnCl}_{2}$ activated coir pith carbon. J. Colloid Interface Sci. 280 359-365.

Nguyen, T.A.H., Ngo, H.H., Guo, W.S., Zhang, J., Liang, S., Tung, K.L., 2013. Feasibility of iron loaded 'okara' for biosorption of phosphorous in aqueous solutions. Bioresour. Technol. 150, 42-49.

Ogata, F., Tominaga, H., Kangawa, M., Inoue, K., Kawasaki, N., 2012. Characteristics of granular boehmite and its ability to adsorb phosphate from aqueous solution. Chem. Pharm. Bull. 60, 985-988.

Okochi, N.C., 2013. Phosphorus Removal from Stome Water Using Electric Arc Furnace Steel Slag (Ph.D. thesis). University of Regina, Canada.

Soy 20/20, 2014. Overview of current utilization. Available at <http:/ www.soy2020.ca/pdfs/OverviewOfOkaraUtilization.pdf/> (Accessed on March 29, 2014).

Unnithan, M.R., Vinod, V.P., Anirudhan, T.S., 2001. Ability of iron(III) loaded carboxylated polyacrylamide grafted sawdust to remove phosphate ions from aqueous solution and fertilizer industry wastewater: adsorption kinetics and isotherm studies. J. Appl. Polym. Sci. 84, 2541-2553.

Zhang L, Wan, L, Chang N., Liu, J., Duan, C, Zhou, Q, Li, X, 2011. Removal of phosphate from water by activated carbon fiber loaded with lanthanum oxide. J. Hazard. Mater. 190, 848-855.

Zhang, J., Shan, W., Ge, J., Shen, Z., Lei, Y., Wang, W., 2012. Kinetic and equilibrium studies of liquid phase adsorption of phosphate on modified sugarcane bagasse. J. Environ. Eng. 138, 252-258. 